\title{
THE EVALUATION OF GREEN SUPPLY CHAIN MANAGEMENT EFFORTS OF TURKISH FIRMS
}

\author{
Banu DEMIREL ${ }^{1}$, KevSer YILMAZ ${ }^{2}$
}

\begin{abstract}
Environmental threats like the devastating impacts of climate change and scarcity of resources require companies to operate in a more eco-friendly way and to take the necessary precautions to preserve the environment. In this context, achieving the profit and market share targets and eliminating their environmental risks and negative effects simultaneously pave the way for the effective management of the supply chains. Green supply chain management (GSCM) aiming at the integration of environmental thinking into supply chain management processes like product design, material procurement and selection, production process, delivery of the final product to the consumer, as well as the management of end-of-life is crucial to increase their environmental efficiency. In this regard, The Carbon Disclosure Project (CDP) emerges as one of the most important efforts to accelerate viable solutions for companies and their supply chains against climate change. Within the scope of the project, the progress of Turkish firms' actions against climate change has been surveyed. Thus, the objective of the current study is to determine the level of the green supply chain activities, and evaluate the adequacy of the current efforts of the firms which responded to the CDP 2017 climate change survey in Turkey and are listed in the industrial category in Istanbul Stock Exchange (BIST) 100. Content analysis will be conducted to analyze the sustainability and/or annual reports of the firms based on the GSCM theoretical framework of Islam et al. (2017). It is hoped that this study will serve as a road map for firms in Turkey in both means of obtaining the gaps in their GSCM efforts and the activities and operations needed to close those gaps.
\end{abstract}

Keywords: Climate Change, Green Supply Chain Management, Supply Chain Management, Sustainability

Jel classification: M10, M11, M19, Q01, Q56

\section{TÜRKIYE'DEKİ FİRMALARIN YEŞIL TEDARİK ZINCİRİ YÖNETIMII UYGULAMALARININ DEĞERLENDİRILLMESI}

\author{
$\ddot{O} z$
}

İklim değişikliğinin yıkıcı etkileri ve kaynakların azlığı gibi çevresel tehditler, firmaları, çevre dostu faaliyetlerini arttırmak ve çevreyi korumak için gerekli önlemleri almaya zorlamaktadır. $\mathrm{Bu}$ çerçevede, kar ve pazar payı hedeflerine ulaşılması aynı zamanda, çevresel riskleri ve bunların olumsuz etkilerinin ortadan kaldırılması, tedarik zinciri yönetiminin etkin bir şekilde gerçekleştirilmesine olanak sağlamaktadır. Yeşil tedarik zinciri yönetimi (YTZY), çevre yanlısı düşünce biçiminin, ürün tasarımı, malzeme temini ve seçimi, üretim süreci, nihai ürünün tüketiciye teslimi gibi tedarik zinciri yönetimi süreçlerine entegre edilmesini amaçlamaktadır. Bu bağlamda, Karbon Saydamlık Projesi (KSP), firmaların ve tedarik zincirlerinin, iklim değişikliğine karşı uygulanabilir çözümlerin arttırılmasına yönelik en önemli çabalardan biri olarak görülmektedir.

1 Assoc. Prof. Dr. Banu Demirel, Dokuz Eylul University, Faculty of Business, Department of Business Administration, Izmir, Turkey, banu.atrek@ deu.edu.tr ORCID: 0000-0002-2487-0313.

2 Research Asst. Kevser Yilmaz, Dokuz Eylul University, Faculty of Business, Department of Business Administration, Izmir, Turkey, kevser.yilmaz@ deu.edu.tr ORCID: 0000-0003-0415-8844. 
Proje kapsamında, Türk firmalarının iklim değişikliği çerçevesindeki uygulamalarının gelişimi incelenmiştir. Bu kapsamda, bu çalışmanın amacı, Türkiye'deki KSP 2017 iklim değişikliği anketine katılan ve İstanbul Menkul Kiymetler Borsası (BIST) 100 indeksinde sanayi kategorisinde listelenen firmaların, yeşil tedarik zinciri faaliyetlerini ortaya koymaktır. İslam vd. (2017) tarafindan oluşturulmuş olan YTZY teorik çerçevesi kapsamında, firmaların, sürdürülebilirlik ve/veya faaliyet raporları, içerik analizi yöntemiyle analiz edilmiş ve Türkiye'deki mevcut çabaların yeterliliği değerlendirilmiştir. Bu çalışmanın, Türkiye'deki firmalara hem YTZY çabalarındaki eksiklikleri hem de bu eksiklilikleri gidermek için gerekli faaliyet ve işlemleri ortaya koyacak bir yol haritası olarak hizmet etmesi beklenmektedir.

Anahtar Kelimeler: İklim Değişikliği, Yeşil Tedarik Zinciri Yönetimi, Tedarik Zinciri Yönetimi, Sürdürülebilirlik

Jel Sinıflaması: M10, M11, M19, Q01, Q56

\section{Introduction}

As the last decades has been characterized with an upward increase in population growth, industrialization and economic development, an incremental rise in the demand of natural resources results in undesirable consequences for both environmental quality and ecological system of the earth (Riedy, 2005). The concepts such as 'climate change', 'sustainable' and 'green' are interchangeably used in the pertinent literature in order to address the impacts of climate change (Rex, et al, 2015). Since the consumption level of human has been accelerated with the effect of growing population, which has damaging impacts on the natural environment and increases climate change (Dietz et al., 2007; Myers \& Kent, 2003), the problem is human induced. In this sense, the human behaviors that contribute to climate change consist of the emissions of three greenhouse gases (GHGs); involving, carbon emissions by the way of the usage of fossil fuels, the emission of methane gases and the release of nitrous oxide (industrial operations and etc.) (van der Linden, 2015).

The problem of scarcity of resources that may arise requires companies to be more conscious about environment and to take precautions in this regard. In this context, firms should manage supply chains effectively by taking into account the fair use of natural resources (Vachon and Klassen, 2006). Green supply chain management (GSCM) emerges as an organization philosophy aiming at increasing the ecological effectiveness of the companies in the chain by minimizing the damage to the environment and at the same time increasing the profit and market share of the firms (van Hoek, 1999; Andiç et al, 2012).

Considering the importance and the urgency of the issue, it is vital to enhance the GSCM practices of the enterprises. Thus, the current study is a pioneer research that aims to identify the practices in terms of GSCM of Turkish firms which responded to the survey of CDP. Furthermore, the adequacy of these efforts are evaluated by identifying the gaps in current practices when compared with the pertinent literature on GSCM.

\section{Theoretical Background}

GSCM is an emerging body of research of the last decade which attracts the attention of both the companies and the scholars due to the climate change and sustainability issues that endangers the quality of lives of the next generations. Therefore, there is a lack of consensus on GSCM definition and scope. 
Nevertheless, the philosophy behind GSCM is to protect the environment by minimizing waste, by applying energy conservation practices, green logistics, green manufacturing and many other upstream and downstream GSCM operations and practices. These practices enable enterprises to increase their economic-environmental performances by reducing their environmental risks while increasing their ecological effectiveness (van Hock and Erasmus, 2000).

GSCM is defined by Srivastava (2007) as the integration of environmental thinking into supply chain management, which includes the processes of managing the end of product life as well as the delivery of the final product to the consumer. Zsidisin and Hendrick (1998) obtained four dimensions of GSCM in their study conducted on purchasing managers in three different countries. The first of these dimensions is the supply chain relations dimension in which suppliers are evaluated within the scope of environmental issues. Return on investment, another dimension, emerges as one of the most common aspects of green supply chain operations. Product design has been found to be the third dimension, which involves designing products so that they can be recycled or reused using less energy and materials. The final dimension, called hazardous materials, deals with the purchase of hazardous materials, chemicals and equipment. Zhu and Sarkis (2004) examine GSCM under different dimensions: the commitment of senior management, support of mid-level management, cross-functional cooperation for environmental improvements, total quality environmental management, environmental compliance and audit programs. On the other hand, in addition to the aforementioned studies, GSCM is also examined under four main activities; green purchasing, green production/material management, green distribution/packaging and reverse logistics (Hervani et al, 2005; Büyüközkan \& Vardaloğlu, 2008). Various other dimensions like senior management and employee participation, green marketing, green supplier, green stock and green environmental design (Van Hoek, 1999; Shang et al, 2010; Chan et al, 2012) have been identified within the efforts of conceptualization of GSCM.

In order to identify the scope of GSCM practices, a structured literature review has been conducted by Islami et al. (2017). The paper analyzes 91 articles published high-quality journals in order to create comprehensive list of aspects and practices of the green supply chain. Based on this study, GSCM has 16 aspects and 58 practices. The aspects are listed as follows:

- Reverse Logistic,

- Industrial Symbiosis,

- Eco-Innovation Practices,

- Green Information Technology and Systems,

- Green Design,

- Carbon Management,

- Supplier Environmental Collaboration,

- Customer Environmental Collaboration,

- ISO 14001 Certification,

- Internal Management,

- Green Purchasing,

- Green Manufacturing,

- Green Packaging,

- Green Logistics,

- Green Outsourcing,

- Green Warehousing. 
As stated in the framework of Islami et al., (2017: 18-23): reverse logistics refers to collecting unused items, sorting and inspecting them, then recycling, reusing, remanufacturing, and disposal whereas industrial symbiosis refers to the association between two or more companies within industries in which the wastes of one partner become the raw materials for another. Green information technology and systems take IT function into green consideration and green design reflects the design of products or services with certain environmental consciousness and be able to trace and manage the retrieval of raw materials out of the environment, the disposal of the product back into the environment. Carbon management aspect focuses on reducing the carbon footprints of the enterprises whereas supplier environmental collaboration and customer environmental collaboration aim to develop cooperative activities to handle environmental activities within the supply chain. Internal management encompasses overall initiatives employed by an organization's top manager to implement green practices in the supply chain. Green purchasing, manufacturing, packaging, logistics, outsourcing and warehousing stand for the basic supply chain processes executed with ecologically consciousness.

\section{Methodology}

\subsection{Sampling and Data Collection}

This exploratory research is conducted on the sustainability or activity reports of Turkish firms, which are listed in "industrial" category in Istanbul Stock Exchange (BIST) 100 and participated in CDP 2017 climate change survey. The mission of the CDP is to correctly utilize the joint power of companies, investors and political leaders to accelerate joint action against climate change.

Today, around 4000 organizations from around 60 countries around the world measure and explain greenhouse gas emissions, water resources management and climate change strategies through the CDP in order to set mitigation targets and improve their performance (CDP Türkiye, 2012). Within the scope of this project, Turkish firms have started to share their greenhouse gas emissions, water resources management and climate change strategies to CDP since 2010. Hence, the rationale behind the restriction of the sample to the CDP 2017 climate change survey participation status is that, the firms that are ready to declare their greenhouse gas emissions, water resources management and climate change strategies would be more likely to be engaged in GSCM practices.

As there are limited number of sustainability reports of the firms in the sample, the research is not limited just to the analysis of sustainability reports. Therefore, both the sustainability or annual activity reports of the industrial firms are downloaded from the official websites of the firms. 
Table 1: Sample of the Study

\begin{tabular}{ll}
\hline Firm & Report Type \\
\hline Alarko Holding A.Ş. & Activity Report \\
Çelebi Hava Servisi A.Ş. & Activity Report \\
Tekfen Holding A.Ş. & Activity Report \\
Aselsan Elektronik Sanayi Ve Ticaret A.Ş. & Sustainability \\
& Report \\
Doğan Şirketler Grubu Holding A.Ş. & Activity Report \\
Trakya Cam Sanayi A.Ş. (T.Şişe ve Cam Fabrikalari & Sustainability \\
A.Ş.) & Report \\
Tav Havalimanlari Holding A.Ş. & Sustainability \\
& Report \\
Pegasus Hava Taşımacılığı A.Ş. & Activity Report \\
Tümosan Motor Ve Traktör Sanayi A.Ş. & Activity Report
\end{tabular}

In 2017, 17 firms were listed in industrial category in BIST100; however, seven of them are not included to sample as they did not respond to the CDP 2017 climate change survey. Moreover, Trakya Cam Sanayi A.Ş. and T.Şişe ve Cam Fabrikaları A.Ş. firms merged during the reporting process and published just one report. As a result, the sample of this study consisted of 9 firms. Company names and the type of the reports are depicted in Table 1.

\subsection{Data Analysis}

The content analysis is conducted by the two authors and data analysis involves several steps. At the outset, open coding process is undertaken by reading through reports several times, taking notes of the GSCM activities practiced by the firms and creating appropriate codes based on the meaning that emerges from the data. A coding sheet is prepared in Excel which is comprised of practices of GSCM proposed by Islami et al. (2017). The codes extracted in the initial analysis are matched with the practices of GSCM and categorized under the appropriate category in the coding sheet. The two authors coded the first two report based on the coding protocol separately. Then they coded the remaining part of data together through making discussions. Discrepancies between codings were discussed and coding protocol is revised until $100 \%$ agreement was reached. Using the refined coding protocol, two scholars coded all content with $90 \%$ inter-coder agreement.

\section{Findings}

Findings reveal 11 aspects and 21 practices of GSCM of the sample. The first four aspects with related practices and what the firms in the sample do as a matter of those practices are illustrated in Table 2. 
The only practice referring to green warehousing aspect is found to be "decreasing inventory levels", and the sub-category contains one green supply chain activity of the firms which is minimum inventory usage. Minimum inventory usage is declared two times in the reports (Table 2).

The second GSCM aspect is green logistics, "environmentally friendly transportation" and "using green fuels such as low sulfur content and alternative fuels such as liquid natural gas" are identified as the two practices embraced by firms. Use of electric vehicle and use of nonpolluting fuel are the only activities pursued under the related practices respectively, with a frequency of one. Activities of Turkish firms within green manufacturing aspect are categorized into one GSCM practice: "cleaner production". However, it should be noted that "generating minimum waste, and reducing environmental pollution" practice depicted in the framework of Islami et al. (2017) is merged into cleaner production practice because expression of firms are not clear to categorize them under generating minimum waste, and reducing environmental pollution practice. The mostly repeated $(f=13)$ activities of this practice is the efficient usage of natural resources and the usage of renewable energy resources $(f=12)$. Moreover, reduction of waste and increasing the energy efficiency items are repeated 11 times in the reports of the firms.

Table 2. Green Warehousing, Green Logistics Green Manufacturing and Green Purchasing Aspects of GSCM

\begin{tabular}{|c|c|c|c|}
\hline ASPECTS & PRACTICES & ACTIVITIES OF FIRMS & $\mathbf{F}$ \\
\hline $\begin{array}{l}\text { Green } \\
\text { Warehousing } \\
(\mathbf{f}=2)\end{array}$ & $\begin{array}{l}\text { Decreasing inventory } \\
\text { levels }(\mathrm{f}=2)\end{array}$ & Minimum inventory usage & 2 \\
\hline \multirow[b]{2}{*}{$\begin{array}{l}\text { Green } \\
\text { Logistics }(f=4)\end{array}$} & $\begin{array}{l}\text { Environmentally friendly } \\
\text { transportation }(\mathrm{f}=1)\end{array}$ & Use of electric vehicles & 1 \\
\hline & $\begin{array}{l}\text { Using green fuels such as } \\
\text { low sulfur content and } \\
\text { alternative fuels such as } \\
\text { liquid natural gas }(\mathrm{f}=1)\end{array}$ & Use of non-polluting fuel & 1 \\
\hline \multirow{6}{*}{$\begin{array}{l}\text { Green } \\
\text { Manufacturing } \\
(\mathrm{f}=74)\end{array}$} & \multirow{6}{*}{$\begin{array}{l}\text { Cleaner production } \\
\text { (Generate minimum waste, } \\
\text { and reduce environmental } \\
\text { pollution during } \\
\text { production) }(\mathrm{f}=74)\end{array}$} & $\begin{array}{l}\text { Taking precautions to avoid } \\
\text { environmental risks in production }\end{array}$ & 2 \\
\hline & & Reduction of waste & 11 \\
\hline & & $\begin{array}{c}\text { Usage of components with reduced } \\
\text { environmental impact }\end{array}$ & 2 \\
\hline & & Production of minimum gas waste & 4 \\
\hline & & Separation of waste at the source & 7 \\
\hline & & $\begin{array}{l}\text { Sending hazardous wastes to } \\
\text { authorized disposal or recovery } \\
\text { companies }\end{array}$ & 2 \\
\hline
\end{tabular}




\begin{tabular}{|c|c|c|c|}
\hline \multirow{5}{*}{$\begin{array}{l}\text { Green } \\
\text { Manufacturing } \\
(\mathbf{f}=74)\end{array}$} & & $\begin{array}{l}\text { Having an environmentally friendly } \\
\text { production facility }\end{array}$ & 4 \\
\hline & & $\begin{array}{c}\text { Usage of renewable energy } \\
\text { resources }\end{array}$ & 12 \\
\hline & & $\begin{array}{c}\text { Efficient usage of natural } \\
\text { resources }\end{array}$ & 13 \\
\hline & & Increasing production efficiency & 6 \\
\hline & & Increasing the energy efficiency & 11 \\
\hline \multirow{6}{*}{$\begin{array}{l}\text { Green } \\
\text { Purchasing } \\
(\mathbf{f}=12)\end{array}$} & \multirow[b]{3}{*}{$\begin{array}{l}\text { Buying environment- } \\
\text { friendly raw materials }(f=7)\end{array}$} & $\begin{array}{l}\text { Purchasing equipment that meets } \\
\text { noise and environmental pollution } \\
\text { prevention criteria }\end{array}$ & 3 \\
\hline & & Purchasing electric vehicles & 1 \\
\hline & & $\begin{array}{l}\text { Purchasing environmentally } \\
\text { friendly materials }\end{array}$ & 3 \\
\hline & \multirow{2}{*}{$\begin{array}{l}\text { Pressuring supplier(s) to } \\
\text { take environmental actions } \\
(\mathrm{f}=3)\end{array}$} & Auditing supplier operations & 2 \\
\hline & & $\begin{array}{l}\text { Asking suppliers to take measures } \\
\text { to reduce environmental risks }\end{array}$ & 1 \\
\hline & $\begin{array}{l}\text { Choice of suppliers by } \\
\text { considering } \\
\text { environmental the } \\
(\mathrm{f}=2)\end{array}$ & $\begin{array}{l}\text { Considering environmental } \\
\text { performances of suppliers in } \\
\text { supplier selection }\end{array}$ & 2 \\
\hline
\end{tabular}

Examples related to green purchasing aspect are categorized into three GSCM practices: "buying environment-friendly raw materials", "pressuring supplier(s) to take environmental actions" and "choice of suppliers by considering the environmental criteria". The first practice of green purchasing, "buying environment-friendly raw materials", involves three activities, which are purchasing equipment that meets noise and environmental pollution prevention criteria ( $\mathrm{f}=3$ ), purchasing environmentally friendly materials $(\mathrm{f}=3$ ) and purchasing electric vehicles $(\mathrm{f}=1)$. The second practice of green purchasing is "pressuring supplier(s) to take environmental actions", which comprehends two activities. First activity is auditing supplier operations and is repeated 2 times and the other activity asking suppliers to take measures to reduce environmental risks was repeated 1 time. The last practice is "choice of suppliers by considering the environmental criteria", which contains one activity that is considering environmental performances of suppliers in supplier selection with a frequency of 2 . 
Table 3. Internal Management Aspect

\begin{tabular}{|c|c|c|}
\hline PRACTICES & ACTIVITIES OF FIRMS & $\mathbf{F}$ \\
\hline \multirow{5}{*}{$\begin{array}{l}\text { Environmental } \\
\text { compliance monitoring } \\
\text { and auditing } \\
(\mathrm{f}=13)\end{array}$} & $\begin{array}{c}\text { To follow the requirements of environmental } \\
\text { laws, regulations and standards }\end{array}$ & 7 \\
\hline & $\begin{array}{l}\text { Taking precautions in every aspects of operations to } \\
\text { avoid pollution }\end{array}$ & 1 \\
\hline & To protect the animals and plants & 1 \\
\hline & $\begin{array}{l}\text { To contribute to the development of environmental } \\
\text { policies and systems }\end{array}$ & 1 \\
\hline & To have an environmental management system & 3 \\
\hline \multirow{7}{*}{$\begin{array}{l}\text { Managerial commitment } \\
\qquad(\mathbf{f}=11)\end{array}$} & $\begin{array}{l}\text { To make efficient use of energy as an element of } \\
\text { corporate culture }\end{array}$ & 1 \\
\hline & Adoption of sustainability as a corporate culture & 3 \\
\hline & To develop committees of sustainability & 1 \\
\hline & To determine environmental objectives & 2 \\
\hline & Monitoring environmental performance regularly & 2 \\
\hline & To acquire an environmental management policy & 1 \\
\hline & $\begin{array}{l}\text { To develop environmentally friendly products and } \\
\text { services }\end{array}$ & 1 \\
\hline $\begin{array}{l}\text { Employee incentive } \\
\text { programs for } \\
\text { environmental } \\
\text { suggestions } \\
(\mathbf{f}=\mathbf{1})\end{array}$ & $\begin{array}{c}\text { To encourage the participation of employees in } \\
\text { environmental activities }\end{array}$ & 1 \\
\hline
\end{tabular}

The fifth GSCM aspect identified in the current study is internal management, which are categorized into three practices. "Environmental compliance monitoring and auditing" is the first sub-category, which comprehends 5 activities. To follow the requirements of environmental laws, regulations and standards item is the activity that is mostly repeated $(\mathrm{f}=7)$ in the reports. As can be seen in Table 3, the second practices category, which the activities of firms fall under, is "managerial commitment", which contains seven green supply chain activities. The highest frequency of firm activity belongs to adoption of sustainability as a corporate culture item $(\mathrm{f}=3)$. 
Table 4. Environmental Certification and Carbon Management Aspects

\begin{tabular}{|c|c|c|c|}
\hline ASPECTS & PRACTICES & ACTIVITIES OF FIRMS & $\mathbf{F}$ \\
\hline \multirow{5}{*}{$\begin{array}{l}\text { Environmental } \\
\text { Certification } \\
\quad(\mathbf{f}=\mathbf{1 5})\end{array}$} & \multirow{5}{*}{$\begin{array}{c}\text { Participating in } \\
\text { environmental } \\
\text { certification such as } \\
\text { ISO } 14001 \text { certificate. } \\
\text { ( } \mathrm{f}=15)\end{array}$} & ISO 14001 certificate & 7 \\
\hline & & $\begin{array}{c}\text { ISO } 50001 \text { Energy Management } \\
\text { System }\end{array}$ & 4 \\
\hline & & $\begin{array}{l}\text { ISO } 14064 \text { Greenhouse Gas Reporting } \\
\text { Standard }\end{array}$ & 2 \\
\hline & & Carbon Accreditation & 1 \\
\hline & & Green Company Certificate & 1 \\
\hline \multirow{7}{*}{$\begin{array}{c}\text { Carbon } \\
\text { Management } \\
(\mathbf{f}=\mathbf{4 0})\end{array}$} & \multirow{6}{*}{$\begin{array}{l}\text { Steps of carbon } \\
\text { reduction } \\
\quad(f=39)\end{array}$} & To calculate carbon footprint & 2 \\
\hline & & Controlling carbon emissions resources & 2 \\
\hline & & $\begin{array}{l}\text { Reporting greenhouse gas emission } \\
\text { performance }\end{array}$ & 3 \\
\hline & & $\begin{array}{c}\text { Reduction of carbon dioxide } \\
\text { emissions }\end{array}$ & 27 \\
\hline & & $\begin{array}{l}\text { Reporting by participating in the CDP } \\
\text { Water Program }\end{array}$ & 1 \\
\hline & & To manage greenhouse gas inventory & 4 \\
\hline & $\begin{array}{l}\text { Training related to } \\
\text { carbon management } \\
\qquad(\mathrm{f}=1)\end{array}$ & $\begin{array}{l}\text { Training personnel on reduction of } \\
\text { carbon dioxide emissions }\end{array}$ & 1 \\
\hline
\end{tabular}

The original aspect in the framework of Islami et al. (2017) is named as ISO 14001 Certification. However, in order to expand the comprehensiveness of the concept, the name is changed as Environmental Certification. Firms' activities related to environmental certification are categorized into one practice: "participating in environmental certification". Under this practice category, acquiring ISO 14001 certificate is the mostly repeated activity ( $\mathrm{f}=7$ ) (See Table 4). Activities referring to the carbon management aspect is categorized into two practice categories: "steps of carbon reduction" and "training related to carbon management". Reduction of carbon dioxide emissions has the highest frequency $(\mathrm{f}=27)$ in this aspect.

Environmental Collaboration is another aspect of GSCM and found to have three practices and 13 activities of firms. The original framework involves Supplier Environmental Collaboration and Customer Environmental Collaboration aspects. However, firms' reports mainly mention the word "stakeholder" but not "suppliers" or "customers" separately. Therefore, these two aspects are merged and are given the name of Environmental Collaboration. 
Table 5. Environmental Collaboration Aspect

\begin{tabular}{|c|c|c|}
\hline PRACTICES & ACTIVITIES OF FIRMS & $\mathbf{F}$ \\
\hline \multirow{8}{*}{$\begin{array}{l}\text { Share environmental } \\
\text { management techniques and } \\
\text { knowledge. } \\
(\mathbf{f}=20)\end{array}$} & $\begin{array}{c}\text { To promote recycling and environmental awareness } \\
\text { within stakeholders }\end{array}$ & 3 \\
\hline & $\begin{array}{l}\text { To support stakeholders to be active players in } \\
\text { sustainable solutions. }\end{array}$ & 2 \\
\hline & $\begin{array}{l}\text { To involve stakeholder expectations in decision- } \\
\text { making processes }\end{array}$ & 1 \\
\hline & $\begin{array}{c}\text { Determining sustainability priorities with } \\
\text { stakeholders }\end{array}$ & 3 \\
\hline & $\begin{array}{l}\text { Sharing environmental management understanding } \\
\text { with stakeholders }\end{array}$ & 4 \\
\hline & $\begin{array}{c}\text { Providing environmental training to } \\
\text { stakeholders }\end{array}$ & 5 \\
\hline & $\begin{array}{l}\text { To reduce environmental impacts with all } \\
\text { stakeholders }\end{array}$ & 1 \\
\hline & Conducting bio-diversity studies with stakeholders & 1 \\
\hline \multirow{3}{*}{$\begin{array}{l}\text { Monitor environmental } \\
\text { compliance status and } \\
\text { practices of stakeholders } \\
\qquad(f=7)\end{array}$} & $\begin{array}{l}\text { Monitoring the activities of stakeholders through a } \\
\text { platform }\end{array}$ & 1 \\
\hline & $\begin{array}{l}\text { Monitoring stakeholder compliance with } \\
\text { environmental policy }\end{array}$ & 3 \\
\hline & Auditing the environmental operations & 3 \\
\hline \multirow{2}{*}{$\begin{array}{c}\text { Communicate goals of } \\
\text { sustainability to } \\
\text { stakeholders }(f=8)\end{array}$} & $\begin{array}{c}\text { Sharing sustainability understanding with } \\
\text { stakeholders }\end{array}$ & 4 \\
\hline & $\begin{array}{l}\text { Adopting a common sustainability understanding } \\
\text { with stakeholders }\end{array}$ & 4 \\
\hline
\end{tabular}

As illustrated in Table 5, "share environmental management techniques and knowledge" practice has the highest frequency among the other practices and contains eight activities. The most repeated activity is found as providing environmental training to stakeholders $(\mathrm{f}=5)$.

The next GSCM aspect found as a result of the analysis is green design. As depicted in Table 6, designing environmental friendly products/services is the most frequently mentioned $(\mathrm{f}=4)$ activities of firms which belong to "intend to reduce products' negative effects on the environment during its entire life cycle" practice category. 
Table 6. Green Design, Green Information Technology and Systems Aspects and EcoInnovation Practices

\begin{tabular}{|c|c|c|c|}
\hline ASPECTS & PRACTICES & ACTIVITIES OF FIRMS & $\mathbf{F}$ \\
\hline \multirow{2}{*}{$\begin{array}{l}\text { Green Design } \\
\qquad(\mathbf{f}=\mathbf{5})\end{array}$} & $\begin{array}{l}\text { Design of products for reduced } \\
\text { consumption of materials/energy. } \\
\qquad(\mathrm{f}=1)\end{array}$ & $\begin{array}{l}\text { To design high performance } \\
\text { new products for effective } \\
\text { thermal insulation and solar } \\
\text { control }\end{array}$ & 1 \\
\hline & $\begin{array}{l}\text { Intend to reduce products' } \\
\text { negative effects on the } \\
\text { environment during its entire life } \\
\text { cycle }(\mathrm{f}=4)\end{array}$ & $\begin{array}{l}\text { Designing environmental } \\
\text { friendly products/services }\end{array}$ & 4 \\
\hline \multirow{4}{*}{$\begin{array}{c}\text { Green } \\
\text { Information } \\
\text { Technology } \\
\text { and Systems } \\
\qquad(\mathbf{f = 1 4 )}\end{array}$} & \multirow{2}{*}{$\begin{array}{c}\text { Use of energy efficient hardware } \\
\text { and data centers }(\mathrm{f}=8)\end{array}$} & $\begin{array}{l}\text { Choosing nature-friendly } \\
\text { systems for hardware } \\
\text { purchases }\end{array}$ & 4 \\
\hline & & $\begin{array}{l}\text { Lower energy consumption in } \\
\text { data center design }\end{array}$ & 4 \\
\hline & \multirow{2}{*}{$\begin{array}{l}\text { Consolidating servers using } \\
\text { virtualization software \& } \\
\text { Collaborative group software. } \\
\qquad(\mathrm{f}=6)\end{array}$} & $\begin{array}{l}\text { Using Building Management } \\
\text { System Automation }\end{array}$ & 1 \\
\hline & & $\begin{array}{c}\text { Use of integrated enterprise } \\
\text { portal }\end{array}$ & 5 \\
\hline \multirow{3}{*}{$\begin{array}{c}\text { Eco- } \\
\text { Innovation } \\
\text { Practices } \\
(\mathbf{f}=13)\end{array}$} & \multirow{3}{*}{$\begin{array}{l}\text { Internal recycling of wastes } \\
\qquad(\mathrm{f}=13)\end{array}$} & $\begin{array}{c}\text { Recovery of energy from } \\
\text { waste }\end{array}$ & 4 \\
\hline & & Reuse of waste & 5 \\
\hline & & $\begin{array}{l}\text { To ensure the recycling of } \\
\text { waste }\end{array}$ & 4 \\
\hline
\end{tabular}

Activities related to Green Information Technology and Systems are categorized into two practice categories: "use of energy efficient hardware and data centers" and "consolidating servers using virtualization software \& collaborative group software". Use of integrated enterprise portal has the highest frequency $(\mathrm{f}=5)$ among the firms' activities within Green Information Technology and Systems aspect. Finally, the last GSCM aspect found appears to be Eco-Innovation Practices in which reuse of waste is the mostly repeated activity $(\mathrm{f}=5)$ among the others in the category.

\section{Conclusion And Discussion}

This research aims to explore the GSCM practices of Turkish firms which are thought to have an inclination towards pursuing GSCM practices and activities. Hence, to fulfill this purpose, the sample of the study is determined according to the response status of the BIST 100 firms within "industry" category to CDP Climate Change survey 2017 which is accepted as a signal of consciousness towards environmental protection. 
Content analysis is conducted on the sustainability/activity reports of the firms based on the GSCM aspects and practices framework of Islami et al. (2017). Findings reveal that Green Manufacturing is the most frequently mentioned aspect of the sample. Efficient usage of natural resources, usage of renewable energy resources, increasing the energy efficiency and reduction of waste are the mostly repeated activities of the firms within Green Manufacturing. The second GSCM aspect which the sample mostly pursue is Carbon Management. Firms in the sample mainly focus on the reduction of carbon dioxide emissions but it is observed that there are no current targets of carbon reduction of the firms and there is a gap in terms of providing sufficient trainings to their employees related to carbon management.

It is gratifying to observe that the firms in the sample collaborate with their stakeholders in terms of environment. They share environmental management techniques and knowledge, monitor environmental compliance status and practices of their stakeholders and communicate their goals of sustainability to their stakeholders. However, they may be advised to collaborate with their stakeholders to build programs to reduce or eliminate waste and to manage reverse flows of materials and packaging. Internal management support is also vital for firms in order to sustain the GSCM practices. Firms claim to perform environmental compliance monitoring and auditing within their firms and claim managerial commitment with the activities of adopting sustainability as a corporate culture, determining environmental objectives and monitoring environmental performance regularly. Nevertheless, they have a lack of employee incentive programs for environmental suggestions.

Findings reveal only 11 aspects of the 16 aspects of GSCM provided in the aforementioned framework. No practices of Reverse Logistics, Green Packaging, Green Outsourcing and Industrial Symbiosis aspects of GSCM are mentioned in the reports of the firms in the sample. However, it should be noted that each GSCM practices may differ according to the sector that the firm operates in. Moreover, the legal requirements and obligations may differ from country to the other. Beyond that, each firm's corporate culture and values may be different which may also affect the way they practice GSCM activities.

Natural resource depletion, the spread of environmental pollution on a global scale and climate change generate deep concern about the sustainability of nature and natural resources. Therefore, it is obvious that firms should be willing to take more responsibility to minimize their negative impacts on the environment. Besides, the pressure from the international environmental bodies and the possible environmental policy and regulation adaptations in line with the combat with the climate change like the possible carbon taxation or limitations on greenhouse gas emissions, may force the firms to realize GSCM practices in all aspects. Therefore, it is recommended that the firms in Turkey integrate green initiatives to their supply chains successfully in the near future.

\section{References}

Andiç, E., Yurt, Ö., \& Baltacioğlu, T. (2012). Green supply chains: Efforts and potential applications for the Turkish market. Resources, Conservation and Recycling, 58, 5068.

Büyüközkan, G. \& Vardaloğlu, Z. (2008). Yeşil Tedarik Zinciri Yönetimi. Lojistik Dergisi, 8, 66- 73. 
Chan, R.Y.K., Hongwei He, H. K. Chan \& Wang, W.Y.C. (2012). Environmental Orientation and Corporate Performance: The Mediation Mechanism of Green Supply Chain Management and Moderating Effect of Competitive Intensity. Industrial Marketing Management, 41, 621-630.

CDP Türkiye, (2012). En İyi Uygulamalar Kitapçı̆̆ı. DOI: 10.5900/SU_SOM_WP.2012.18931.

Dietz, T., Rosa, E. A. \& York, R. (2007). Driving the human ecological footprint. Frontiers in Ecology and the Environment, 5(1), 13-18.

Hervani, A.A., Helms, M.M. \& Sarkis, J. (2005). Performance Measurement for Green Supply Chain Management. Benchmarking: An International Journal, 12(4), 330-353.

Myers, N., \& Kent, J. (2003). New consumers: the influence of affluence on the environment. Proceedings of the National Academy of Sciences, 100(8), 4963-4968.

Rex, J., Lobo, A., \& Leckie, C. (2015). Evaluating the drivers of sustainable behavioral intentions: An application and extension of the theory of planned behavior. Journal of Nonprofit \& Public Sector Marketing, 27(3), 263-284.

Riedy, C. (2005) The eye of the storm: An integral perspective on sustainable development and climate change response. (Doctoral Dissertation, University of Technology, Sydney, Australia). Retrieved August 18, 2018 from: http://hdl.handle.net/10453/20350.

Shang, K., Lu, C. \& Li, S. (2010). A Taxonomy Of Green Supply Chain Management Capability Among Electronics-Related Manufacturing Firms in Taiwan. Journal of Environmental Management, 91, 1218-1226.

Srivastava, S. K. (2007). Green Supply-Chain Management: A State-Of-The-Art Literature Review. International Journal of Management Reviews, 9(1), 53-80.

Vachon, S. \& Klassen, R.D. (2006). Green Project Partnership In The Supply Chain: The Case of The Package Printing Industry. Journal of Cleaner Production, 14 (6-7), 661-671.

Van Hock, R.I. \& Erasmus. (2000). From Reversed Logistics to Green Supply Chains. Logistics Solutions, 2, 28-33.

Van Hoek, R. I. (1999) From Reversed Logistics to Green Supply Chains. Supply Chain Management: An International Journal, 4 (3), 129 - 135.

Zsidisin, G.A. \& Hendrick, T.E. (1998). Purchasing's Involvement in Environmental Issues: A Multi-Country Perspective. Industrial Management and Data Systems, 7, 313-320.

Zhu, Q. \& Sarkis, J. (2004). Relationships Between Operational Practices and Performance Among Early Adopters of Green Supply Chain Management Practices in Chinese Manufacturing Enterprises. Journal of Operations Management, 22, 265-289. 